\title{
Stent-in-stent, a safe and effective technique to remove fully embedded esophageal metal stents: case series and literature review
}

Authors

Institution
Alberto Aiolfi, Davide Bona, Chiara Ceriani, Matteo Porro, Luigi Bonavina

University of Milan, Department of Biomedical Sciences for Health, Division of General Surgery, IRCCS Policlinico San Donato, Milan, Italy submitted 23. October 2014 accepted after revision 7. January 2014

\section{Bibliography}

Dol http://dx.doi.org/

10.1055/s-0034-1391419

Published online: 24.6.2015

Endosc Int Open 2015; 3: E296-E299

(c) Georg Thieme Verlag KG Stuttgart · New York

E-ISSN 2196-9736

\section{Corresponding author} Luigi Bonavina, MD, FACS Divisione Universitaria di Chirurgia

IRCCS Policlinico San Donato Piazza Edmondo Malan 2 20097 San Donato Milanese Milan

Italy

Fax: +39-02-52774622

luigi.bonavina@unimi.it
Background: Endoscopic stenting is a widely used method for managing esophageal anastomotic leaks and perforations. Self-expanding metal stents (SEMSs) have proved effective in sealing these defects, with a lower rate of displacement than that of self-expanding plastic stents (SEPSs) as a result of tissue proliferation and granulation tissue ingrowth at the uncovered portion of the stent, which anchor the prosthesis to the esophageal wall. Removal of a fully embedded stent is challenging because of the risk of bleeding and tears.

Materials and methods: Temporary placement of a new stent within the first stent (stent-in-stent technique) may facilitate the mobilization and safe removal of both stents by inducing pressure ischemia of the granulation tissue. We report our own experience with the stent-in-stent technique

\section{Introduction}

$\nabla$

The management of esophageal perforations and postoperative leaks is still controversial. Prompt endoscopic stenting and drainage of perivisceral collections has been shown to be effective and may improve survival [1]. Introduced for the palliation of malignant dysphagia, self-expanding metal stents (SEMSs) are increasingly used worldwide in the management of leaks despite the lack of Food and Drug Administration (FDA) approval [2]. The incidence of stent migration is lower that with self-expanding plastic stents (SEPSs) because of the proliferation of granulation tissue and subsequent embedding of the uncovered portion of the mesh, which acts as anchor $[3,4]$. The amount of granulation tissue depends on a combination of factors, such as type and size of the stent, radial and axial force, and the duration of stenting ( $>2$ weeks). The removal of SEMSs is challenging and frequently associated with bleeding and mucosal tears [5]. Temporary placement of a new stent within the first stent (stent-in- in five consecutive patients in whom a partially covered Ultraflex stent had previously been implanted and compare our results with those in the current literature.

Results: The first SEMSs remained in place for a median of 40 days (range 18-68) without displacement. Placement of the new stent was technically successful in all patients. All stents were left in place for a median of 9 days. The overall stent-in-stent success rate was $100 \%$ for the removal of embedded stents. No serious adverse events related to the procedure occurred.

Conclusion: The procedure was safe, well tolerated, and effective. The use of a partially covered Ultraflex stent of the same size as the old stent for a limited time ( $\leq 6$ days) was consistently successful.

stent technique) may facilitate mobilization and safe removal of the embedded stent by inducing pressure necrosis of the granulation tissue [6]. We report our experience with the stent-in-stent procedure in patients previously treated for esophageal postoperative leaks, perforations, and malignant dysphagia and compare our results with those in the current literature.

\section{Patients and methods \\ $\nabla$}

Between July 2001 and August 2014 at our institution, 238 partially or fully covered SEMSs were placed for the palliation of malignant dysphagia $(n=198)$ and for the management of esophageal perforations or postoperative leaks $(n=40)$. The stent-in-stent technique was used to remove an embedded stent in four patients with previous anastomotic leak or perforation and in one patient undergoing chemoradiotherapy for squamous cell esophageal carcinoma. Patient data were retrieved from the medical charts. The hos- 


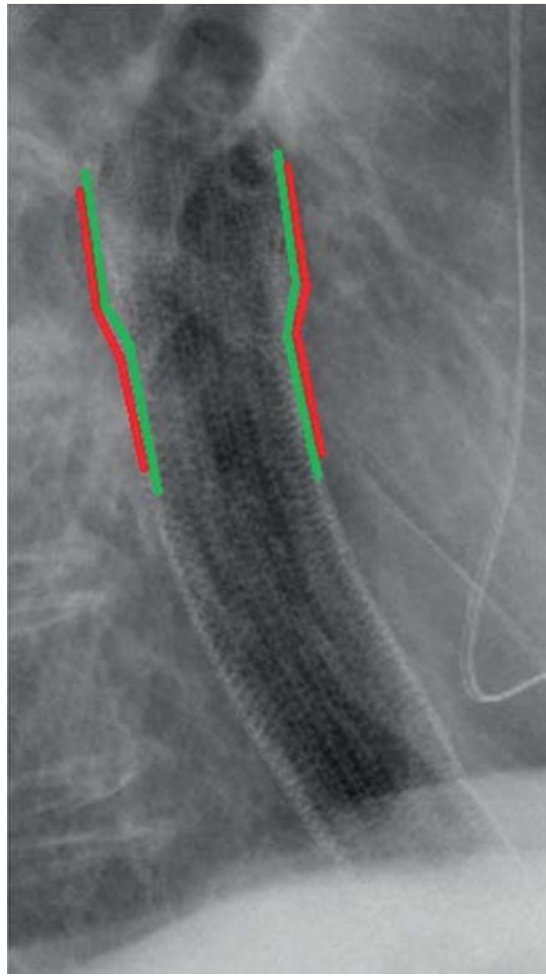

Fig. 1 Stent-in-stent technique to remove a fully embedded esophageal metal stent. Care is taken to ensure that the new stent completely overlaps the reactive tissue ingrowth inside the lumen of the old partially covered stent. Lateral chest radiograph shows almost complete overlapping of two Ultraflex esophageal stents after a stent-in-stent procedure. This results in optimal radiation pressure over the inflammatory/ granulation tissue. The red line corresponds to the first stent, and the green line to the new stent. pital internal review board approved the use of the stent-in-stent technique. Informed consent was obtained for all endoscopic procedure.

Before placement of the initial stent, upper gastrointestinal (GI) endoscopy, a Gastrografin swallow study, and thoraco-abdominal computed tomography (CT) were routinely performed. Before endoscopic intervention, patients with anastomotic leak or perforation underwent percutaneous drainage of perivisceral collections under ultrasound or CT guidance. Diagnostic upper GI endoscopes (EG29-i10; Pentax Medical, Tokyo, Japan) were used for stent positioning and removal. All procedures were performed in the operating room with the patients under general anesthesia. The site of the lesion was marked with external radiopaque markers, and the stents were deployed under fluoroscopic guidance. In all patients, a partially covered, proximal release Ultraflex stent (Boston Scientific, Natick, Massachusetts, USA) was implanted.

The technical success of the procedure was immediately evaluated with endoscopy (correct position of the stent without air leak) and fluoroscopy. Chest radiography and a Gastrografin swallow study on the following day were used to check the position of the stent and sealing of the fistula; if no evidence of leakage was found, patients were allowed to start a semi-liquid diet. After a variable period of time, upper GI endoscopy for possible stent removal was performed. When the stent was found to be embedded and immediate removal was not considered possible, a new partially or fully covered SEMS was placed inside the lumen of the first stent to induce pressure necrosis according to the stent-instent technique.

All secondary procedures were performed in the operating room with the patients under general anesthesia and with fluoroscopic assistance. The new deployed stent had a diameter that was at least equal to that of the first embedded stent in order to provide sufficient radial pressure. Care was taken to ensure that the new stent completely overlapped the reactive tissue ingrowth inside the lumen of the old partially covered stent ( $\bullet$ Fig. 1 ). Ultraflex and Wallflex SEMSs (Boston Scientific) were used for the stentin-stent technique. Removal of the stents was planned after at least 6 days. During the removal procedure, both stents were grasped at the proximal cup purse string with an endoscopic snare or rat-toothed forceps. In only one case, the old stent had to be grasped at the distal margin and inverted. No overtubes were used during removal.

\section{Results}

Five patients (four men and one woman) with a median age of 59.6 years (range $32-86$ ) were treated with six stent-in-stent procedures. The indications for stent placement were esophagojejunal anastomotic leak following total gastrectomy $(n=2)$, esophago-gastric anastomotic leak following subtotal esophagectomy $(n=1)$, iatrogenic esophageal perforation during pneumatic dilation for caustic stricture $(n=1)$, and palliation of dysphagia due to squamous cell carcinoma of the upper thoracic esophagus $(n=1)$ ( Table 1$)$. Placement of the first partially covered nitinol stent was technically successful in all patients. The SEMSs remained in place for a median of 40 days (range 18-68) without displacement. The Gastrografin swallow study revealed no extravasation of contrast, and all patients resumed a semi-liquid diet. Follow-up endoscopy demonstrated complete embedding (>80\% of the circumference) of the proximal and distal cups of the stent (৫ Fig. 2).

Placement of the new stent was technically successful in all patients ( Table 2). A partially covered stent (Ultraflex) was insert-

Table 1 Indications for stent placement and outcome of the primary stent implant in five patients.

\begin{tabular}{|c|c|c|c|c|c|c|}
\hline Patient & Indication & $\begin{array}{l}\text { Distance from } \\
\text { incisors, cm }\end{array}$ & Size of lesion & Stent (stent size) & $\begin{array}{l}\text { Time stent } \\
\text { in situ, } \mathbf{d}\end{array}$ & $\begin{array}{l}\text { Stent ingrowth, percen- } \\
\text { tage circular extension }\end{array}$ \\
\hline 1 & latrogenic perforation & 30 & $5 \mathrm{~mm}$ & $\begin{array}{l}\text { Ultraflex } 12 \mathrm{~cm} \\
(28-23 \mathrm{~mm})\end{array}$ & 64 & $100 \%$ \\
\hline 2 & $\begin{array}{l}\text { Anastomotic leak after total } \\
\text { gastrectomy }\end{array}$ & 37 & $1 / 3$ of circumference & $\begin{array}{l}\text { Ultraflex } 10 \mathrm{~cm} \\
(23-18 \mathrm{~mm})\end{array}$ & 68 & $80 \%$ \\
\hline 3 & $\begin{array}{l}\text { Anastomotic leak after total } \\
\text { gastrectomy }\end{array}$ & 38 & $1 / 3$ of circumference & $\begin{array}{l}\text { Ultraflex } 12 \mathrm{~cm} \\
(28-23 \mathrm{~mm})\end{array}$ & 18 & $80 \%$ \\
\hline 4 & $\begin{array}{l}\text { Anastomotic leak after subtotal } \\
\text { esophagectomy }\end{array}$ & 30 & $10 \mathrm{~mm}$ & $\begin{array}{l}\text { Ultraflex } 12 \mathrm{~cm} \\
(28-23 \mathrm{~mm})\end{array}$ & 26 & $100 \%$ \\
\hline 5 & $\begin{array}{l}\text { Palliation of squamous cell } \\
\text { carcinoma }\end{array}$ & 20 & $5 \mathrm{~cm}$ & $\begin{array}{l}\text { Ultraflex } 12 \mathrm{~cm} \\
(23-18 \mathrm{~mm})\end{array}$ & 25 & $100 \%$ \\
\hline
\end{tabular}




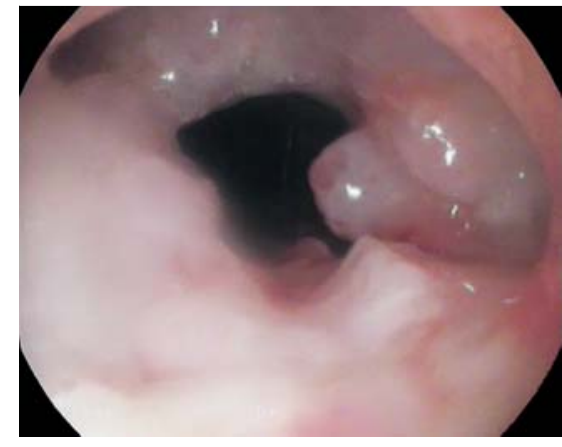

Fig. 2 Endoscopic view of complete embedding of the proximal cup of the Ultraflex stent. The reactive inflammatory tissue completely overlaps the uncovered proximal portion of the mesh ( $100 \%$ circumferential ingrowth).

ed in four procedures, and a fully covered nitinol stent (Wallflex) in two. All stents were left in place for a median of 9 days (range $6-17)$. In four patients, the stents were successfully removed at the planned date ( Fig. 3 ). In the patient with esophageal tumor, it was decided to remove the stent because of the onset of dyspnea related to extrinsic compression of the trachea and left main bronchus. In one patient, complete embedding of the proximal end of the first stent was seen after removal of the second fully covered stent at 17 days after implant. Another partially covered nitinol stent was then placed, and both stents were easily removed after 6 days. The procedural time for removal varied between 20 and 30 minutes.

The overall stent-in-stent success rate for the removal of embedded stents was $100 \%$. No serious adverse events related to the procedure occurred. In one patient, a reduced fistula size but persistent anastomotic leakage was noted after stent removal, and an Over-the-Scope Clip (OTSC; Ovesco Endoscopy AG, Tübingen,
Germany) was successfully deployed. One patient developed dysphagia 2 months after the stent-in-stent procedure, which resolved after Savary bougie dilation of an anastomotic stricture. No further complications occurred during a minimum follow-up time of 5 months.

\section{Discussion}

$\nabla$

Over the past decade, stent placement has developed and emerged as an effective and potentially life-saving treatment for patients with esophageal perforations and postoperative leaks [7]. Currently, most of the available data concern plastic stents (SEPSs), which are the only FDA-approved removable stents [8]. However, stent migration due to a lack of proper anchorage to the esophageal wall occurs in up to $88 \%$ of these patients and is a source of major morbidity [9-11]. Fixing with endoclips has been suggested, with controversial results [12]. Despite the lack of FDA approval, SEMSs seem preferable to SEPSs because the embedded uncovered mesh may serve as an anchor, ensuring adequate sealing with lower displacement rates. The extent of tissue granulation overgrowth varies among studies ( $0-47 \%)$ [13]. No relationship has been found between the extent of the tissue response and the specific type of SEMS or previous chemotherapy and/or radiotherapy. Stent material and radial force have been suggested to have a role. It is well-known that the tissue reaction increases with time, but strong stent embedding can already be seen as early as 10 to 15 days after placement. The tissue response consists of well-vascularized granulation tissue, reac-

Table 2 Outcome of stent-in-stent procedure in five patients.

\begin{tabular}{|c|c|c|c|c|c|}
\hline Patient & Stent (stent size) & $\begin{array}{l}\text { Time to removal of } \\
\text { both stents, } d\end{array}$ & Removal procedure & Outcome & Follow-up, mo \\
\hline 1 & $\begin{array}{l}\text { Wallflex } 15 \mathrm{~cm} \\
(25-18-23 \mathrm{~mm})\end{array}$ & 12 & Uncomplicated & No visible fistula & 26 \\
\hline 2 & $\begin{array}{l}\text { Wallflex } 15 \mathrm{~cm} \\
(25-18-23 \mathrm{~mm})\end{array}$ & 17 & $\begin{array}{l}\text { Ultraflex still embedded at } \\
\text { the proximal cup ( } 75 \% \text { of } \\
\text { circumference) }\end{array}$ & $\begin{array}{l}\text { Placement of Ultraflex } 10 \mathrm{~cm} \\
(23-18 \mathrm{~mm}) \text {; successful removal } \\
\text { after } 6 \text { days; no visible fistula }\end{array}$ & 22 \\
\hline 3 & $\begin{array}{l}\text { Ultraflex } 12 \mathrm{~cm} \\
(28-23 \mathrm{~mm})\end{array}$ & 6 & Uncomplicated & No visible fistula & 17 \\
\hline 4 & $\begin{array}{l}\text { Ultraflex } 12 \mathrm{~cm} \\
(28-23 \mathrm{~mm})\end{array}$ & 6 & Uncomplicated & $\begin{array}{l}\text { Small residual fistula ( } 2 \mathrm{~mm}) \text {; } \\
\text { endoclip application }\end{array}$ & 15 \\
\hline 5 & $\begin{array}{l}\text { Ultraflex } 12 \mathrm{~cm} \\
(23-18 \mathrm{~mm})\end{array}$ & 6 & Uncomplicated & Reduction of dyspnea & 5 \\
\hline
\end{tabular}
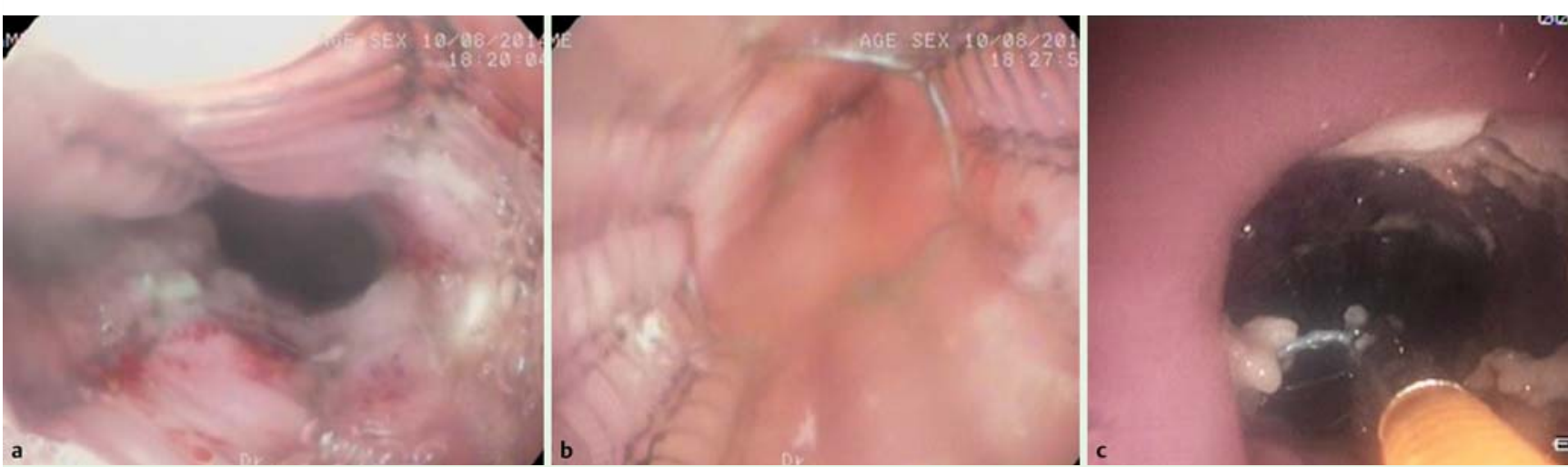

Fig. 3 The proximal (a) and distal (b) cups of the old Ultraflex stent after the stent-in-stent procedure. There is no evidence of residual granulation tissue. The rat-toothed forceps are useful to grasp the proximal retrieval string for removal (c). 
Table 3 Stent-in-stent procedure: literature overview.

\begin{tabular}{|c|c|c|c|c|c|c|c|c|c|c|}
\hline \multirow[t]{2}{*}{ First Author } & \multirow[t]{2}{*}{ Year } & \multirow{2}{*}{$\begin{array}{l}\text { Patients, } \\
\text { n }\end{array}$} & \multirow{2}{*}{$\begin{array}{l}\text { Procedures, } \\
\text { n }\end{array}$} & \multirow[t]{2}{*}{ Type of stent } & \multicolumn{4}{|c|}{ Indication for primary stent implant } & \multirow{2}{*}{$\begin{array}{l}\text { Complication } \\
\text { rate, \% }\end{array}$} & \multirow{2}{*}{$\begin{array}{l}\text { Success } \\
\text { rate, \% }\end{array}$} \\
\hline & & & & & Leak & Perforation & $\begin{array}{l}\text { Benign } \\
\text { stricture }\end{array}$ & $\begin{array}{l}\text { Malignant } \\
\text { stricture }\end{array}$ & & \\
\hline Evrard [3] & 2004 & 5 & 5 & SEPS & - & 3 & 2 & - & 0 & 100 \\
\hline Tunç̈zgür [6] & 2006 & 1 & 1 & SEPS & - & - & 1 & - & 0 & 100 \\
\hline Eisendrath [4] & 2007 & 11 & 11 & SEPS & 11 & - & - & - & 0 & 100 \\
\hline Hirdes [14] & 2011 & 19 & 23 & $\begin{array}{l}12 \text { BD, } 9 \text { SEPS, } \\
2 \text { SEMS (Niti-S) }\end{array}$ & 7 & 8 & 1 & 3 & $\begin{array}{l}\text { Severe bleed- } \\
\text { ing }(n=1)\end{array}$ & 91 \\
\hline Vasilikostas [15] & 2014 & 5 & 5 & SEMS (Wallflex) & 4 & - & 1 & - & 0 & 100 \\
\hline Present series & & 5 & 6 & $\begin{array}{l}\text { SEMS ( } 2 \text { Wall- } \\
\text { flex, } 4 \text { Ultraflex) }\end{array}$ & 3 & 1 & - & 1 & 0 & 100 \\
\hline Total & & 46 & 51 & & & & & & & \\
\hline
\end{tabular}

SEPS, self-expanding metal stent; BD, biodegradable stent; SEMS, self-expanding metal stent.

tive hyperplasia, and fibrotic tissue penetrating through the uncoated mesh of the stent [5].

The removal of embedded stents is challenging and associated with bleeding or mucosal tears. Argon plasma coagulation (APC) has been found to be time-consuming, technically demanding, and associated with significant complications $[2,4]$. Previous reports have already shown that the radial force of a second stent placed within the first stent results in pressure ischemia and necrosis of granulation tissue, facilitating successful mobilization with subsequent removal of both stents (stent-in-stent technique) $[14,15]$.

Our results with the stent-in-stent technique are similar to those reported in other series, in which, with one exception [15], plastic stents have been used in the majority of patients ( $\bullet$ Table 3 ). However, we believe that using the same type of partially covered metal stent, with a diameter and length identical to those of the old one, optimizes the contact surface between the two prostheses and can maximize ischemic pressure. This strategy was successful in four of our patients. In addition, the Ultraflex stents caused negligible tissue overgrowth in their uncovered portion, presumably because of the short implantation time ( $\leq 6$ days).

\section{Conclusion}

We conclude that the stent-in-stent technique, despite the need of an additional endoscopic procedure with the insertion of a new stent and extra costs, is technically feasible, safe, and effective for the removal of partially covered stents that have become partially or totally embedded in the esophageal wall.

\section{Competing interests: None}

\section{References}

1 Pross M, Manger T, Reinheckel T et al. Endoscopic treatment of clinically symptomatic leaks of thoracic esophageal anastomoses. Gastrointest Endosc 2000; 51: 73-76

2 Siersema PD, Homs MY, Haringsma J et al. Use of large-diameter metallic stents to seal traumatic non-malignant perforations of the esophagus. Gastrointest Endosc 2003; 58: 356-361

3 Evrard S, Le Moine O, Lazaraki G et al. Self-expanding plastic stents for benign esophageal lesions. Gastrointest Endosc 2004; 60: 894-900

4 Eisendrath P, Cremer M, Himpens J et al. Endotherapy including temporary stenting of fistulas of the upper gastrointestinal tract after laparoscopic bariatric surgery. Endoscopy 2007; 39: 625-630

5 Siersema PD, Hirdes MM. What is the optimal duration of stent placement for refractory, benign esophageal strictures? Nat Clin Pract Gastroenterol Hepatol 2009; 6: 146-147

6 Tunçözgür B, Savaş MC, Işik AF et al. Removal of metallic stent by using Polyflex stent in esophago-colic anastomotic stricture. Ann Thorac Surg 2006; 82: $1913-1914$

7 Gelbmann CM, Ratiu NL, Rath HC et al. Use of self-expandable plastic stents for the treatment of esophageal perforations and symptomatic anastomotic leaks. Endoscopy 2004; 36: 695-699

$8 \mathrm{Ott}$ C, Ratiu N, Endlicher E et al. Self-expanding Polyflex plastic stent in esophageal disease: various indications, complications, and outcomes. Surg Endosc 2007; 21: 889-896

9 Radecke K, Gerken G, Treichel U. Impact of a self-expanding, plastic esophageal stent on various esophageal stenosis, fistulas, and leakages: a single-center experience in 39 patients. Gastrointest Endosc 2005; 61: 812-818

10 Freeman RK, Van Woerkom JM, Vyverberg A et al. Esophageal stent placement for the treatment of spontaneous esophageal perforations. Ann Thorac Surg 2009; 88: 194-198

11 Pennathur A, Chang AC, McGrath KM et al. Polyflex expandable stents in the treatment of esophageal disease: initial experience. Ann Thorac Surg 2008; 85: 1968 - 1972

12 Silva RA, Dinis-Ribeiro M, Brandao $C$ et al. Should we consider endoscopic clipping for prevention of esophageal stent migration? Endoscopy 2004; 36: 369-370

13 Homs MY, Steyerberg EW, Kuipers EJ et al. Causes and treatment of recurrent dysphagia after self-expanding metal stent placement for palliation of esophageal carcinoma. Endoscopy 2004; 36: 880-886

14 Hirdes MM, Siersema PD, Houben MH et al. Stent-in-stent technique for removal of embedded esophageal self-expanding metal stents. Am J Gastroenterol 2011; 106: 286-293

15 Vasilikostas G, Sanmugalingam N, Khan $O$ et al. 'Stent in a stent' - an alternative technique for removing partially covered stents following sleeve gastrectomy complications. Obes Surg 2014; 24: 430-432 